\title{
TRUST AND COMMITMENT: DO THEY INFLUENCE E-CUSTOMER RELATIONSHIP PERFORMANCE?
}

\author{
Nor Azila Mohd Noor \\ University Utara Malaysia \\ 06010 Sintok, Kedah, Malaysia \\ azila@uum.edu.my
}

\begin{abstract}
Customer relationship management can help companies build lasting relationships with their customers. Today, CRM has dramatically changed because the internet can be used for CRM applications. Thus, Electronic Customer relationship management (e-CRM) is a comprehensive business and marketing strategy that integrates people, processes, technology and all business activities for attracting and retaining customers through the internet and mobile phones. E-CRM results in repeat purchases, word of mouth, retention, cross buying, brand loyalty and customer satisfaction. The keen competition in the communication and mobile phone service market place and the increasing numbers of mobile phone users worldwide has influenced researchers to investigate factors that contribute to e-CRM performance. This study investigates the influence of customer trust and commitment on e-CRM performance in the Jordanian mobile phone services industry. The analysis shows that customer trust and commitment were positively related to e-CRM performance.
\end{abstract}

Keywords: Customer Relationship Management, Electronic Customer Relationship Management, Trust, Commitment

\section{INTRODUCTION}

Customer Relationship Management (CRM) has become the main strategy to retain customers for companies, regardless of size. A company's customer care strategy and its CRM software go hand in hand ${ }^{1}$. It costs up to five times more to acquire a new customer than to get an existing customer to make a new purchase ${ }^{2}$. According to $\mathrm{Wu}$ and $\mathrm{Wu}^{3}$, the damage caused by a dissatisfied customer can be expanded exponentially, as they are more 
likely to defect to competition and more likely to convince others to switch their service provider. Today, CRM is a significant issue for discussion in the academic and business arena. CRM within businesses has increased dramatically over the last years, and will continue to do so in the future. The relationship between customer and service provider will become more challenging and competitive as the number of customers increases, leading service providers focus on their services and software to manage the critical relationships with their subscribers.

Long-term relationships with customer is the key to stability in an increasingly dynamic market ${ }^{3}$ so, CRM is replacing the traditional 'four Ps' of marketing (product, price, place and promotion). The introduction of the internet has changed the situation because it can be integrated with CRM solutions. E-CRM emerges from the internet and web technology to facilitate the implementation of CRM. It focuses on web-based interaction between customer and service provider ${ }^{2}$. Aydin and $\mathrm{Ozer}^{4}$ defined e-CRM as marketing activities, tools and techniques delivered over the internet (using technologies such as web sites and e-mail, data capture, ware housing and mining) with the specific aim to locate, build and improve long term customer relationships to enhance individual business potential. E-CRM can use alternative channels like e-mail, websites, wrap sites, voice mail, SMS, MMS, product information online, 1-800 telephone, call back button, chat, electronic bulletin boards and links ${ }^{3}$.

The mobile phone service industry has enormous potential for growth in most parts of the world. Due to the many alternatives available to customers, they can easily switch service providers. Recent technological changes have shifted competition from price and core service to value-added services $(\mathrm{e}-\mathrm{CRM})^{4}$, so operators should differentiate their services and guaranteed their service quality. The standards of professionalism in e-CRM performance and mobile phone service should be raised in response to the shift in customer's needs and preference. Accordingly, managing customer's expectations, needs and desires has become a major concern of service providers due to various factors such as keen business competition, liberalization of the industry to foreign service providers, ease of switching service provider to competitors and increasing customer preference and needs. To remain competitive, the mobile phone service providers have to create new business models and produce innovative content and applications that can attract and retain consumers. By implementing e-CRM and focusing on customer satisfaction and loyalty, they can provide services based on customer need and expectations ${ }^{5}$. 
Despite the importance of CRM to the success of the organization, empirical studies on e-CRM performance context have been less than encouraging. Furthermore, the majority of works on e-CRM performance conducted in the Western countries have focused on e-CRM performance from the firms and employees' perspectives ${ }^{6,7}$. Thus, Khalifa and Shen ${ }^{8}$ recommended that scholars begin considering the e-CRM performance from the customers' perspective. Therefore, this research seeks to address the question, "what underlying factors influence electronic customer relationship management in mobile phone service industry". The objective of this research is to examine the influence of customer trust and commitment on e-CRM performance.

\section{LITERATURE REVIEW}

Customer relationship management (CRM) is a new concept within businesses that has grown dramatically more important over the last few years. CRM is simply the practical application of long standing relationship marketing principles that have existed since the dawn of business itself ${ }^{3,9}$. Implementing CRM successfully can bring several benefits and profits to the companies and help to gain mutual benefits from both parties. Chen ${ }^{6}$ indicated that CRM could bring many benefits for companies, enhancing their ability in the competitive market, increasing profits and profit rate, reducing costs, upgrading concentration of the market, reducing cycle times of implementation of new sales activities, increasing times of small-sized target marketing and increasing knowledge. Likewise, Fjermestad and Romana $^{10}$ indicated that several benefits might be derived from CRM: increased customer loyalty, more effective marketing, improved customer service and support, and greater efficiency and cost reduction.

CRM performance is the success of creating value for customers by increasing retention, repurchase sales and word of mouth marketing for customers to improve relationship quality with the company ${ }^{7}$. When CRM works properly, it helps to solve the problems by engaging everyone together and focusing the whole organization on the customer. It instills the customer with a sense of expectation, Loyalty and relationship between company and customer ${ }^{11}$. Competitors will find such a strong relationship difficult to break ${ }^{12}$.

E-CRM is a combination of hardware, software, process, applications and management commitment to improve customer service, retain customers and provide analytical capabilities ${ }^{13}$. Many companies have spent large amounts of money pursuing the development of a comprehensive e-CRM strategy, but many companies remain dissatisfied with e-CRM 
implementation because e-CRM projects are not creating measurable income on investment ${ }^{14}$.

Few academic studies have examined the factors contributing to e-CRM performance. Many researchers have studied influential factors of customer satisfaction and loyalty in e-commerce. From other studies, Choi et al. ${ }^{15}$ gleaned eight factors: convenience, transaction process, website reliability, information, site design, customer service, price, and security/privacy. Lutz ${ }^{16}$ studied the factors that influence the behavior of customer service workers during customer interactions, finding that person-to-person interactions between customers and employees greatly affect a customer's overall relationship with a company. Hurley and Hult ${ }^{17}$ discovered that innovating new products and services would affect the CRM performance. Similarly, research by Chen, Chem, and Kazman ${ }^{18}$ found that CRM employee knowledge, employee business knowledge and CRM training are among the employee factors that have a positive relationship on CRM performance.

An additional factor influencing e-CRM performance is customer trust $^{19}$. All social relationships would fail and not able to function normally without trust $^{20}$, and it is the cornerstone for a successful and lasting customer relationship. It largely determines the customer's future behavior and loyalty towards the business ${ }^{21}$. Trust has been defined as users' thoughts, feelings, emotions, or behaviors that occur when customers feel that the provider can be relied upon to act in their best interest when they give up direct control ${ }^{20,22}$.

In the context of e-commerce, trust beliefs include online consumers' beliefs and expectancies about characteristics of the online seller ${ }^{23}$. The online consumers desire online sellers to be willing and able to act on the consumers' interests, to be honest in transactions (not divulging personal information to other vendors), and to be capable of delivering the ordered goods as promised. A number of studies indicate that lack of trust is still one of the main factors for customers failing to commit transactions over the internet $^{24}$. Lack of trust is a primary obstacle to e-commerce and by implication -CRM ${ }^{25,26}$. Gefen ${ }^{9}$ argued that lack of trust has been one of the most significant reasons for customers not adopting online services. Researchers have suggested that online customers generally stay away from vendors whom they do not trust ${ }^{27}$. Moreover, trust is important in the online environment, affecting customer's perceptions and willingness to participate and establish relationships with suppliers online ${ }^{28,29,30}$. Many researchers agree that lack of trust regarding the internet and e-CRM is a critical issue that needs addressing. Researchers warn that a lack of trust may be the most significant long-term barrier to realizing the full potential 
of e-commerce ${ }^{31,13,33}$. We hypothesized that:

H1: Customer trust of mobile phone service is positively related to e-CRM performance.

Another factor affecting e-CRM performance is customer commitment. Marketing literature considers this variable to be a significant factor necessary for the creation, building and maintenance of relationships ${ }^{34,35}$. The notion of customer commitment has been introduced and used widely in marketing and organizational environments, defined as a desire to maintain a relationship with service provider ${ }^{36,37,38}$. Cook and Emerson ${ }^{39}$ considered behavioral commitment as a critical variable to differentiate social from economic exchange. However, little is known about the potential role of commitment in e-commerce and e-CRM performance ${ }^{40}$.

The past research proposed commitment as an essential construct contributing to successful long-term relationships between buyers and sellers $^{34,38,40}$. They characterized commitment as a lasting desire for businesses and to maintain a valued relationship with their customers. The commitment exists and survives when the customer considers the relationship to be important. Commitment has a significant influence on customers' behavioral intentions online; committed customer recommends online service to other customers and friends and give positive word of mouth about services.

Extending the notion of commitment to e-commerce, Mukherjee and Nath $^{41}$ indicated that commitment has positive effects on customers' online behavioral intentions. Lee, Kozar, and Larsen ${ }^{40}$ also found that internet customers spend more time shopping on the internet and have higher customer satisfaction and loyalty. They considered commitment as central to internet commerce between businesses and customers. Customer commitment is a critical factor in the communication industry and internet since committed customers help companies deliver customer value and enhance performance. However, the effect of customer commitment on e-CRM performance is not understood clearly and represents a gap in the relevant research literature. Therefore, we hypothesized that:

$\mathrm{H} 2$ : Customer commitment to mobile phone services is positively related to e-CRM performance. 


\section{METHODOLOGY}

Data were collected by self-report questionnaires from university students in Jordan. Many previous studies have employed university students as subjects ${ }^{19,42}$. University students belong to a specific population that typically has more internet/mobile phone experience, better skills, and higher education levels than "other groups ${ }^{43}$. Furthermore, Gefen ${ }^{19}$ found that university students were the heaviest users of mobile phones, followed by high school students and non-student adults. Of 850 questionnaires distributed, 488 were usable and used for subsequent analysis, giving a response rate of 57.41 percent. It was found that $42.4 \%$ respondents were male and $57.6 \%$ were female with majority at the age $20-30$ years old. $7.6 \%$ of the respondents were doctoral degree students, $18.2 \%$ were masters degree students while $74.2 \%$ were undergraduate students.

\section{CONSTRUCT MEASUREMENT}

The operationalization of each construct consisted of multi-item scales based on scales used in past studies. Cronbach's alpha is used to test the reliability of a multi-item scale and the cut off point is $0.6^{44}$. As shown in table 1, all the measures were reliable. To ensure consistency among variables and to avoid confusion, all items were measured using a 1-5 point Likert scale $^{45}$. There is a common belief that e-CRM performance should be measured in terms of customer behaviors since they are main sources of value. Because the primary purpose of e-CRM is to increase revenue and customer lifetime value, customer behaviors that might bring revenue become strategically important ${ }^{46}$. However, e-CRM performance is operationalized by tangible as well as intangible aspects. Tangible aspects refer to customer behavior-based e-CRM performance such as customer retention, repurchase, cross buying and word-of-mouth, while the intangible aspects of e-CRM performance is represented by customer satisfaction and brand loyalty ${ }^{7}$. E-CRM performance is operationalized based on nine items adopted from Wang et al. .

Customer trust is operationalized by three dimensions: the extent that customer rely on mobile phone service provider, enhance self confidence and complete tasks effectively ${ }^{4}$. Eight items adopted from Aydin and Ozer ${ }^{4}$ and $\mathrm{Li}$, Browne, and $\mathrm{Chau}^{47}$ were used to measure the construct. In this research, customer commitment is operationalized by using two dimensions: affective and continuance commitment. Affective commitment refers to the affective or emotional attachment to the service provider and enjoy membership $^{13}$, whereas, the continuance commitment construct was developed to explain the extent that customer feel emotionally attached with 
a service provider. Eight items were used to measure these two dimensions based on the scale developed by Fullerton ${ }^{48}$.

Table 1. Means, standard deviations and reliabilities of measures $(\mathrm{N}=488)$

\begin{tabular}{cccc}
\hline Variable & M & SD & Reliability \\
\hline e-CRM & 4.45 & .45 & .94 \\
Customer trust & 3.96 & .48 & .64 \\
Customer commitment & 3.83 & .56 & .69 \\
\hline
\end{tabular}

\section{RESULTS}

$\mathrm{H} 1$ and $\mathrm{H} 2$ were tested using multiple regression following the guidelines of Ackfeldt and Coole ${ }^{45}$.Correlations between the constructs were derived prior to performing the actual hypotheses tests. Table 2 shows the correlation structure of the data used in this study.

Table 2. Correlation matrix amongst constructs

\begin{tabular}{cccc}
\hline & $\begin{array}{c}\text { e-CRM } \\
\text { performance }\end{array}$ & $\begin{array}{c}\text { Customer } \\
\text { trust }\end{array}$ & $\begin{array}{c}\text { Customer } \\
\text { commitment }\end{array}$ \\
\hline e-CRM performance & 1.0 & & \\
Customer trust & $.67^{* *}$ & 1.0 & \\
Customer commitment & $.47^{* *}$ & $.36^{* *}$ & 1.0 \\
\hline
\end{tabular}

Note: $* * p<0.01$

As Table 2 shows, positive correlations exist between e-CRM performance and customer trust $(r=.67 ; p<.01)$ as well as customer commitment $(r=.47 ; p<.01)$ suggesting support for the hypothesised relationship. In order to identify the strength of the relationship and to explore the predictive ability of customer trust and commitment on e-CRM performance, the hypotheses were tested using a multiple regression prediction model ${ }^{44}$ with e-CRM performance as the dependent variable. The results obtained reveal that customer trust and commitment were found to be significant in the prediction model, as shown in Table 3 . The results provide support for $\mathrm{H} 1$ and $\mathrm{H} 2$, that is, positive relationships between customer trust $(\beta=.09 ; p<.01)$ and customer commitment $(\beta=.45 ; p<.01)$ on e-CRM performance. The $\mathrm{R}^{2}$ shows a value of 0.16 , which indicated that 16 percent of the variations in e-CRM performance is contributed by the element of trust and commitment. 
Table 3. The influence of customer trust and commitment on e-CRM performance

\begin{tabular}{cccc}
\hline $\begin{array}{c}\text { Independent } \\
\text { variable }\end{array}$ & $\mathrm{B}$ & SEB & $\beta$ \\
\hline $\begin{array}{c}\text { Customer trust } \\
\text { Customer }\end{array}$ & 0.12 & 0.05 & $0.09^{* *}$ \\
commitment & 0.56 & 0.05 & $0.45^{* *}$ \\
\hline
\end{tabular}

Note: $R^{2}=0.16 ; F=41.02$; Sig. $F=0.00 ; * p<.05$; B = Unstandardized Beta Coefficients; $\mathrm{SEB}=$ Unstandardized Coefficients Standard Error; $\beta=$ Standardized Beta Coefficients.

\section{DISCUSSIONS}

Based on the correlations between these factors, we can conclude that customer commitment and customer trust significantly influence e-CRM performance.

This study found a significant relationship between customer commitment and e-CRM performance (measured by customer retention, repurchase, cross buying and word-of-mouth, customer satisfaction and brand loyalty). This finding is also consistent with previous research by Dimitriades ${ }^{49}$ and Aydin et al. ${ }^{50}$ who found that customer commitment is positively associated with customer loyalty and satisfaction. Committed customers have the easiest relationship to manage and are not particularly price sensitive. Therefore, if the service providers do not take care of committed customers, the relationship with the service provider can weaken.

Recently, customer retention has become a major challenge for many service providers and an essential contributor to profitability and loyalty over the long term. The problem many managers face is that, although their customers state they are happy and satisfied, they often still switch to competing suppliers ${ }^{51}$. The basic truth is that satisfied customers are not necessarily loyal customers. True loyalty is the major objective of the mobile phone service providers.

At the same time, there is an interactive commitment between customer and service provider. This builds on the work of Somers ${ }^{52}$ in organizational behavior and the work of Heide and John ${ }^{53}$ in relationship marketing. The findings suggest that the impact of customer retention depends on the level of customer commitment. Lack of customer commitment may produce negative word of mouth, damage the company's image and harm the company's reputation ${ }^{9,46,54,55}$. These effects could reduce the mobile phone service provider's opportunities of acquiring and retaining customers. In addition, the service provider needs to invest resources in attracting new 
customers to replace the ones it has lost. Consequently, retaining the current customer base is much more attractive than searching for new customers ${ }^{55}$.

This research has found a positive relationship between customer trust and e-CRM performance in the context of mobile phone service in Jordan, which is in line with the findings of past studies $4,6,56,57,58$. These studies have found that trust is an important factor on purchase intention toward online shopping. Additionally, our finding is consistent with Aydin and Ozer ${ }^{4}$, who discovered a positive relationship between trust in the mobile phone service provider and customer loyalty in the Turkish mobile telecommunication market. However, our finding is not consistent with that of $\mathrm{Wu}$ and $\mathrm{Liu}^{59}$, who did not find the direct effect of trust in online game websites on intention to play but found instead an indirect effect through the attitude towards playing online games. This is possibly because the focus of their study was online game websites intention, but our study was mobile phone service industry.

Trust generally is viewed as an essential factor for successful relationships. The success of a mobile phone service provider depends on their customers, so consumer trust is critical for the mobile phone service industry. In the marketing context, trust is the basis of an interpersonal relationship and a commercial relationship ${ }^{60}$. Likewise, lack of trust is a critical issue on e-business transaction success. All parties involved in any business have to have trust in the people and companies with whom they do business. Trust has been recognized as playing an important role in affecting customer relationship commitment and customer loyalty ${ }^{61}$. It is clear that if one party trusts another, it is likely to develop some form of positive behavioral intention towards the other party. Accordingly, when a customer trusts a mobile phone service provider, this means that he/she is also likely to form a positive actual usage intention towards the service provider. In this manner, the greater level of customer trust in mobile phone service providers is expected to lead to fewer concerns about customer privacy and price increase. However, in many traditional business relationships, trust is based on a combination of judgments or opinions based on face-to-face meetings or the recommendations of colleagues, friends and business partners, which may not apply to e-commerce.

\section{LIMITATIONS AND FUTURE RESEARCH DIRECTIONS}

This study provides an innovative step on the antecedents of e-CRM performance in the context of the mobile phone services industry in Jordan. From a methodological point of view, data in this research were obtained 
from Jordanian university students. It would be useful to obtain a broader sample of respondents in future studies. Another limitation is associated with the use of self-completion survey methods. Even though survey research is the most widely used approach, it is associated with a number of problems. The lack of researcher control in the self-completion process necessitates that the resultant data sample will not be fully representative of the population, as valid respondents may choose not to complete the survey. In addition, respondents sometimes give expected answers or pattern responses to questions.

The few limitations of this study provide suggestions for further research. The current study has excluded the impact of moderating variable on the relationships between the independent variable and e-CRM performance. As a first attempt to draw an overview of the research area and to control the scope of the study, we focused on the independent variable and its relationship to e-CRM performance. Testing the moderating impact is important and may give the picture richness that requires future investigation. This study is concerned about the e-CRM performance in mobile phone services in Jordan. Replicating and extending this study in other regions and countries and other services would test the generalizability of the present findings and would provide a basis for an external validation of the framework developed in this research to understand the cultural and geographical variations of customer behavior.

\section{CONCLUSIONS}

These findings provide additional evidence to the growing body of knowledge concerning the importance of achieving higher levels of e-CRM performance. This study has contributed to the marketing literature by shedding some light on e-CRM issues that had not been widely examined in the literature. It has also contributed to the telecommunications sector literature, where little investigation has taken place on issues concerning e-CRM in telecommunications companies. It can be concluded that factors influencing the performance of e-CRM performance are quite diverse in their nature and origin. The present research suggests customer trust and customer commitment as important factors that can contribute to e-CRM performance. We believe that the current study provides beneficial implications for both academic research and practitioners based on an insightful review of the existing work on e-CRM performance. 


\section{REFERENCES}

[1] H. Baumeister, Customer relationship management for SMEs. Muchen: Institute für Informatic Press, 2002.

[2] B. Silverstein, Business-to-business internet marketing. Florida: Maximum Press, 2000.

[3] L. Wu, and K. Wu, A hybrid technology acceptance approach for exploring e-CRM adoption in organizations. Behavior \& Information Technology, 24(4), p303-316, 2005. doi:10.1080/0144929042000320027.

[4] S. Aydin, and G. Ozer, The analysis of antecedents of customer loyalty in the Turkish mobile telecommunication market. European Journal of Marketing, 39(7/8), p910-925, 2005. doi:10.1108/03090560510601833.

[5] C.I. Gura u, Tailoring e-service quality through CRM. Managing Service Quality, 13(6), p520-531, 2003. doi:10.1108/09604520310506577.

[6] S.L. Chen, The relationship between customer loyalty and customer satisfaction. International Journal of Contemporary Hospitality Management, 13(5), p213-219, 2001.

[7] Y. Wang, H.P. Lo, R. Chi, and Y. Yang, An integrated framework for customer value and customer-relationship management performance: A customer-based perspective from China. Managing Service Quality, 14(2/3), p169-182, 2004. doi:10.1108/09604520410528590.

[8] M. Khalifa, and N. Shen, Effects of electronic customer relationship management on customer satisfaction: A temporal model. Paper presented at the 38th Annual Hawaii International Conference on System Sciences, Big Island, Hawaii, USA, January 3-6, 2005. doi:10.1109/HICSS.2005.224.

[9] E. Gummesson, Return on relationships (ROR): The value of relationship marketing and CRM in business-to-business contexts. The Journal of Business and Industrial Marketing, 19(2), p136-148, 2004. doi:10.1108/08858620410524016.

[10] J. Fjermestad, and N. Romano, An integrative implementation framework for electronic customer relationship management: Revisiting the general principles of usability and resistance. Paper presented at the 36th Hawaii International Conference on System Sciences, Big Island, Hawaii, USA, January 6-9, 2003. doi:10.1109/HICSS.2003.1174394.

[11] J. Gummerus, V.P.M. Liljander, and A.V. Riel, Customer loyalty to content-based Web sites: The case of an online health-care service. Journal of Services Marketing, 18(3), p175-186, 2004. doi:10.1108/08876040410536486. 
[12] H. Suresh, Customer relationship management: An opportunity for competitive advantage. Retrieved on November 8, 2008, from http://crm.ittoolbox.com/documents/peer-publishing/customer-relations hip management -an-opportunity-for-competitive-advantage-2569\#.

[13] N.C. Romano, and J. Fjermestad, Electronic commerce customer relationship management: An assessment of research. International Journal of Electronic Commerce, 6(2), p61-113, 2002.

[14] B. Goldenberg, What is CRM? What is an e-customer? Why you need them now. Paper presented at the DCI Customer Relationship Management Conference, Boston, MA, June 27-29, 2000.

[15] J. Choi, H. Seol, S. Lee, H. Cho, and Y. Park, Customer satisfaction factors of mobile commerce in Korea. Internet Research, 18(3), p313-335, 2008. doi:10.1108/10662240810883335.

[16] B.B.R. Lutz, Human and organizational factors that affect CRM success: Do your employees help create a positive relationship with your customers? Retrieved on October 2, 2008, from http://www.destinationcrm.com/Articles/WebExclusives/Viewpoints/H uman-and-Organizational-Factors-That-Affect-CRM-Success.

[17] R.F. Hurley, and G.T Hult, Innovation, market orientation, and organizational learning: An integration and empirical examination. Journal of Marketing, 62(3), p42-54, 1998. doi:10.2307/1251742.

[18] H.M. Chen, Q. Chen, and R. Kazman, The affective and cognitive impacts of perceived touch on online customers' intention to return in the Web-based e-CRM environment. Journal of Electronic Commerce in Organizations, 5(1), p69-91, 2007. doi:10.4018/jeco.2007010104.

[19] D. Gefen, E-Commerce: The role of familiarity and trust. The International Journal of Management Science, 28(6), p725-737, 2000. doi:10.1016/S0305-0483(00)00021-9.

[20] A.S. Patrick, Building trustworthy software agents. IEEE Internet Computing, 6(6), p46-53, 2002. doi:10.1109/MIC.2002.1067736.

[21] L.L. Berry, and A. Parasuraman, Marketing service. New York, NY: Free Press, 1991.

[22] P.A. Pavlou, Consumer acceptance of electronic commerce: Integrating trust and risk with the technology acceptance model. International Journal of Electronic Commerce, 7(3), p101-134, 2003.

[23] D.H. McKnight, and N.L. Chervany, Conceptualizing trust: A typology and e-Commerce customer relationships model. Paper presented at the 34th Annual Hawaii International Conference on System Science, Maui, Hawaii, USA, January 3-6, 2001. doi:10.1109/HICSS.2001.927053.

[24] L. Ang, C. Dubelaar, and B.C. Lee, To trust or not to trust? A model of internet trust from the customer's point of view. Paper presented at the 14th Bled Electronic Commerce Conference, Bled, Slovenia, June 25-26, 2001. 
[25] M.L. Roberts, Internet marketing: Integrating online and offline strategies. Boston: McGraw-Hill Irwin, 2003.

[26] M.M. Head, and K. Hassanein, Trust in e-Commerce: Evaluating the impact of third-party seals. Quarterly Journal of Electronic Commerce, 3(3), p307-325, 2002.

[27] F.F. Reichheld, and P. Schefter, E-loyalty: Your Secret weapon on the Web. Harvard Business Review, 78(4), p105-113, 2000.

[28] D. Gefen, and D. Straub, The relative use of perceived ease of use in IS adoption: A study of e-commerce adoption. Journal of the Association for Information Systems, 1(8), p1-28, 2000.

[29] D. Gefen, E. Karahanana, and D. Straub, Trust and TAM in online shopping: An integrated model. MIS Quarterly, 27(1), p51-90, 2003.

[30] N. Luhmann, Trust and power. London: Wiley, 1979.

[31] P.G.W. Keen, Are you ready for 'trust' economy? Computer World, 31(2), p79-80, 1997.

[32] D.L. Hoffman, T.P. Novak, and M. Peralta, Building customer trust online. Communications of the ACM, 42(4), p80-85, 1999.

[33] M. Roy, O. Dewit, and B. Aubert, The impact of interface usability on trust in Web retailers. Internet Research: Electronic Networking Applications and Policy, 11(5), p388-398, 2001. doi:10.1108/10662240110410165.

[34] F. Dwyer, P. Schurr, and O. Sejo, Developing buyer-seller relationships. Journal of Marketing, 51(2), p11-27, 1987. doi:10.2307/1251126.

[35] N.J. Allen, and J.P. Meyer, The measurement and antecedents of affective, continuance and normative commitment to the organization. Journal of Occupational Psychology, 63(1), p1-18, 1990. doi:10.1111/j.2044-8325.1990.tb00506.x.

[36] C. Moorman, G. Zaltman, and R. Deshpande, Relationships between providers and users of marketing research: The dynamics of trust within and between organizations. Journal of Marketing Research, 29(3), p314-329, 1992. doi:10.2307/3172742.

[37] M.A. Iniesta, and M. S'anchez, Retail-consumer commitment and market segmentation. The International Review of Retail, Distribution and Consumer Research, 12(3), p261-279, 2002. doi:10.1080/09593960210139661.

[38] R.M. Morgan, and S.D. Hunt, The commitment-trust theory of relationship marketing. Journal of Marketing, 58(3), p20-38, 1994. doi: $10.2307 / 1252308$.

[39] K.S. Cook, and R.M. Emerson, Power, equity and commitment in the exchange networks. American Sociological Review, 43(5), p721-739, 1978. doi:10.2307/2094546.

[40] Y. Lee, K. Kozar, and K. Larsen, The technology acceptance model: Past, present, and future. Communications of the Association for 
Information Systems, 12, p752-780, 2003.

[41] M.A. Mukherjee, and P. Nath, Role of electronic trust in online retailing: A re-examination of the commitment-trust theory. European Journal of Marketing, 41(9/10), p1173-1202, 2007. doi:10.1108/03090560710773390.

[42] L. DeBaillon, and P. Rockwell, Gender and student status differences in cellular telephone use. International Journal of Mobile Communications, 3(1), p82-98, 2005. doi:10.1504/IJMC.2005.005876.

[43] N. Li, and P. Zhang, Consumer online shopping behavior. In J. Fjermestad and N. Romano (Eds.), Customer Relationship Management, Series of Advances in Management Information Systems (p52-65), New York, NY: M.E. Sharpe, 2005.

[44] J. Hair, R. Anderson, R. Tatham, and W. Black, Multivariate data analysis (5th ed.). Upper Saddle River: Prentice-Hall Inc, 1998.

[45] A.L. Ackfeldt, and L.V. Coole, A study of organizational citizenship behavior in a retail setting (electronic version). Journal of Business Research, 58(2), p151-159, 2003. doi:10.1016/S0148-2963(03)00110-3.

[46] R.N. Bolton, K.N. Lemo, and P.C. Verhoef, The theoretical underpinnings of customer asset management: A framework and propositions for future research. Rotterdam: ERIM Publication, 2002. doi:10.1177/0092070304263341.

[47] D. Li, G.J. Browne, and P.Y.K. Chau, An empirical investigation of Web site use using a commitment-based model. Decision Sciences, 37(3), p427-444, 2006. doi:10.1111/j.1540-5414.2006.00133.x.

[48] G. Fullerton, When does commitment lead to loyalty? Journal of Service Research, 5(4), p333-342, 2003. doi:10.1177/1094670503005004005.

[49] Z.S. Dimitriades, Customer satisfaction, loyalty and commitment in service organizations some evidence from Greece. Management Research News, 29(12), p782-800, 2006. doi:10.1108/01409170610717817.

[50] S. Aydin, G.K. Ozer, and O. Arasil, Customer loyalty and the effect of switching costs as a moderator variable: A case in the Turkish mobile phone market. Marketing Intelligence \& Planning, 23(1), p89-103, 2005. doi:10.1108/02634500510577492.

[51] N. Terblanche, Customer commitment to South African fast food brands: An application of the Conversion Model. Management Dynamics, 25(1), 11-18, 2008.

[52] M. Somers, Organizational commitment, turnover, and absenteeism: An examination of direct and indirect effects. Journal of Organizational Behavior, 16(1), p49-58, 1995. doi:10.1002/job.4030160107. 
[53] J.B. Heide, and G. John, Do norms matter in marketing relationships? Journal of Marketing, 56(2), p32-44, 1992. doi:10.2307/1252040.

[54] K.H. Kim, J.Y. Park, D.Y. Kim, H.I. Moon, and H.C. Chun, E-Lifestyle and motives to use online games. Irish Marketing Review, 15(2), p71-77, 2002.

[55] J.H. Cheong, and M.C. Park, Mobile internet acceptance in Korea. Internet Research, 15(2), p125-140, 2005. doi:10.1108/10662240510590324.

[56] A. Chaudhuri, and M.B. Holbrook, The chain of effects from brand trust and brand affect to brand performance the role of brand loyalty. Journal of Marketing, 65(2), p81-93, 2001. doi:10.1509/jmkg.65.2.81.18255.

[57] D. Sirdeshmukh, J. Singh, and B. Sabol, Consumer trust, value, and loyalty in relational exchanges. Journal of Marketing, 66(1), p15-37, 2002. doi:10.1509/jmkg.66.1.15.18449.

[58] J. Singh, and D. Sirdeshmukh, Agency and trust mechanisms in consumer satisfaction and loyalty judgments. Journal of the Academy of Marketing Science, 28(1), p150-167, 2000. doi:10.1177/0092070300281014.

[59] J. Wu, and D. Liu, The effects of trust and enjoyment on intention to play online games. Journal of Electronic Commerce Research, 8(2), p128-140, 2007

[60] P. Guenzi, and O. Pelloni, The impact of interpersonal relationships on customer satisfaction and loyalty to the service provider. International Journal of Service Industry Management, 15(4), p365-384, 2004. doi:10.1108/09564230410552059.

[61] G. Gundlach, and P. Murphy, Ethical and legal foundations of relational marketing exchanges. Journal of Marketing, 57(4), p35-46, 1993. doi:10.2307/1252217. 
